\title{
The Influence of Students' Beliefs on Mathematical Problem Solving towards Mathematics Achievement among Malaysian Matriculation Students
}

\author{
Suriati Abu Bakar ${ }^{1, *}$, Ahmad Fauzi Mohd Ayub ${ }^{1,2}$, Kathiresan Gopal', Nur Raidah Salim ${ }^{1}$ \\ ${ }^{1}$ Institute for Mathematical Research, Universiti Putra Malaysia, Malaysia \\ ${ }^{2}$ Faculty of Educational Studies, Universiti Putra Malaysia, Malaysia
}

Received July 31, 2019; Revised September 9, 2019; Accepted September 23, 2019

Copyright $(\mathrm{C} 2019$ by authors, all rights reserved. Authors agree that this article remains permanently open access under the terms of the Creative Commons Attribution License 4.0 International License

\begin{abstract}
The purpose of this study is to investigate beliefs on mathematical problem solving among matriculation students. Five factors of students' beliefs on mathematical problem solving, i.e., difficult problems, steps, understanding, word problems and effort were investigated to predict factors that influence their mathematics achievement. The study sample consisted of 312 matriculation students from three matriculation colleges. The questionnaire was adapted from the Indiana Mathematics Beliefs Scale (IMBS) and a mathematics test. The results of the data analysis indicated that students have positive beliefs about mathematical problem solving. The findings showed that there is a positive significant relationship between the overall beliefs with mathematics achievement. Three sub-factors, i.e., difficult problems, steps and understanding were found to have positive significant relationship with mathematics achievement. Furthermore, by using the multiple regression analysis, it was revealed that difficult problems, steps and understanding contributed significantly to students' mathematics achievement.
\end{abstract}

Keywords Difficult Problems, Steps, Understanding, Problem Solving, Mathematics Beliefs, Mathematics Achievement

\section{Introduction}

In the past three decades, researches had revealed the importance of beliefs in shaping students' cognitive and affective activities in mathematical classrooms. Students' beliefs about mathematical problem solving is an important component for their participation in mathematics learning activities and mathematics achievement [1]. In fact, previous studies have shown that students' beliefs in mathematics are influential in students' intentions to pursue mathematics related studies or careers [2]. However, certain beliefs about mathematical problem solving tend to negatively affect students' ability to engage productively in problem solving at all levels of education [3]. Positive beliefs would motivate students and increase their success in problem solving process. Mostly, these students would make an effort to solve problems. Therefore, it is important for mathematics teachers to assist students to become more interested in problem solving by improving their mathematical beliefs. This can be done by improving students' abilities in applying problem solving skills and expanding types of problems that enable students to solve mathematics problems in their classrooms so that they can see its importance to career opportunities in mathematics $[4,5]$.

Mathematics beliefs refer to a student's belief which is something known or felt that affects the effort to learn mathematics [6]. For example, if students believe learning mathematical problem solving will be valuable, then they will put in more effort in learning. Belief about mathematics, according to Mason and Scrivani [7], are powerful in shaping students' behavior. Thus, understanding students' beliefs on mathematical problem solving is important in mathematics curriculum. This understanding would help teachers to implement more effective programmes for poor performers in problem solving [1].

Lerch's [8] study on college students found that an individual's personal beliefs affect how they approach mathematics problems and thus guided their progress in problem solving situations. Past studies have shown that beliefs could affect students' learning and achievement. For instance, Garcia [9] found there is a significant relationship between beliefs about mathematics and 
algebra achievement among college students. Similarly, Abdul Kadir et al.'s [10] study among undergraduate students also demonstrated positive significant relationship between mathematical problem solving belief and mathematics achievement. Other studies also found mathematics beliefs were significantly related to mathematics achievement [11-13]. Abedalaziz and Akmar [1] found that all five components of beliefs about mathematical problem solving significantly predicted mathematics achievement among secondary school students. Meanwhile, Burrus and Moore [14] exhibited that subjective norms and perceived control, which are two beliefs components, have significantly influenced mathematics achievement. Considering all these previous studies, it is evident that students' beliefs are imperative in mathematics teaching and learning.

Social Cognitive Theory (SCT) had related interactions between behavioral factors, personal characteristics and environmental influences on students' learning. According to SCT, the individuals' beliefs, thoughts and feelings would influence how they react. Schoenfeld [15] identified the influence of beliefs systems that shaped students' behavior as they tried to solve mathematics problems. Students' beliefs on mathematics could also determine how they approach a problem, which strategies to be used or avoided and how long they persevered when solving mathematics problems [16]. Previous researches had reported students' beliefs about mathematical problem solving with classroom activities could predict their achievement in mathematics [17]. Students who constructed more advanced and productive beliefs about mathematics helped them to improve their problem solving strategies and solved mathematics problems more accurately [7]. Therefore, identifying students' beliefs about mathematical problem solving is important in teaching and learning mathematics.

\section{Methods}

This quantitative correlational study employed a cluster sampling procedure. A total of 312 students from the matriculation programme under the Ministry of Education Malaysia were randomly selected. A list of colleges in the North, Central and South zones were acquired and based on random sampling, three colleges were selected for the actual data collection process. The selected colleges were Kolej Matrikulasi Perak (North zone), Kolej Matrikulasi Negeri Sembilan (Central zone) and Kolej Matrikulasi Melaka (South zone). A survey questionnaire was used for the data collection. The data were collected using 28 items adapted from the Indiana Mathematics Beliefs Scale by Kloosterman and Stage [18] to measure students' beliefs about mathematical problem solving. A mathematics test was conducted to determine the students' mathematics achievement. The instrument to measure students' beliefs about mathematical problem solving consisted of five factors, i.e., (a) difficult problems (6 items); (b) steps (4 items); (c) understanding (6 items); (d) word problems (6 items) and effort (6 items).

According to Kloosterman and Stage [18], difficult problems measure students' beliefs to solve time-consuming mathematics problems. Steps relate to students' beliefs about mathematics word problems that cannot be solved by following procedural step. Meanwhile, understanding indicates students' beliefs about the importance to understand why a particular procedure is correct rather than to get the right answer. Word problems measure students' perceptions of the importance of solving word problems rather than computational skills. Finally, effort measures students' beliefs that efforts can strengthen their mathematics ability and thus make them more skilful in mathematics. Respondents were given options using a five-point Likert scale ranging from 1 (strongly disagree) to 5 (strongly agree) to measure their agreement on the questionnaire statements. Whereas mathematics achievement was determined on the total score obtained in mathematics test.

The data were analysed using the IBM SPSS Statistics Version 22 software. The relationship between students' beliefs about mathematical problem solving and mathematics achievement were calculated utilising the Pearson Product-Moment Correlation technique. The multiple regression analysis was performed to find out the best predictors of students' beliefs about mathematical problem solving in mathematics achievement. Before conducting multiple regression analysis, Hair et al. [19] suggested that the sample size, normality, linearity, homoscedasticity and homoscedasticity of residuals assumptions need to be considered.

\section{Results and Discussion}

A total of 312 respondents were randomly selected in this study, which consisted of 106 males (34.0\%) and 206 $(66.0 \%)$ females. The results of the descriptive statistics indicated students' beliefs about mathematical problem solving were based on mean scores ranging from 3.08 to 4.74 (Table 1). The overall mean of students' beliefs about mathematical problem solving was $3.80(\mathrm{SD}=0.28)$, which indicated that students held high positive beliefs about mathematics.

Table 1. Mean and Standard Deviation for Students' Beliefs on Mathematical Problem Solving

\begin{tabular}{|c|c|c|}
\hline Variables & Mean & SD \\
\hline Effort & 4.74 & 0.34 \\
\hline Understanding & 3.97 & 0.56 \\
\hline Difficult problems & 3.64 & 0.54 \\
\hline Word problems & 3.30 & 0.45 \\
\hline Steps & 3.08 & 0.58 \\
\hline Overall students' mathematics beliefs & 3.80 & 0.28 \\
\hline
\end{tabular}


Table 2. Relationship between Students' Beliefs about Mathematical Problem Solving towards Mathematics Achievement

\begin{tabular}{|c|c|c|c|c|c|c|c|}
\hline & & $\begin{array}{c}\text { Difficult } \\
\text { Problems }\end{array}$ & Steps & Understanding & $\begin{array}{c}\text { Word } \\
\text { problems }\end{array}$ & $\begin{array}{c}\text { Overall mathematics } \\
\text { beliefs }\end{array}$ \\
\hline \multirow{2}{*}{ Achievement } & $\mathrm{r}$ & $0.419^{* *}$ & $0.343^{* *}$ & $0.251^{* *}$ & 0.070 & -0.019 \\
\cline { 2 - 7 } & $\begin{array}{c}\text { Sig. } \\
(2 \text {-tailed) }\end{array}$ & 0.000 & 0.000 & 0.000 & 0.218 & $0.748^{* *}$ \\
\hline
\end{tabular}

Effort obtained the highest mean score obtained from the descriptive analysis (Mean $=4.74, \mathrm{SD}=0.34)$. This finding indicated that the students believed that efforts would improve their mathematics ability and they could succeed in mathematics. They believe they could get smarter and improve their ability in mathematics by putting in more effort when solving mathematics problems.

The second highest mean was understanding (Mean = $3.97, \mathrm{SD}=0.56$ ). This showed students were highly inclined to believe the importance to understand as to why a particular procedure was correct rather than getting the right answer. They agreed they should spend time to understand why the answer was correct rather than to get the right answer when solving mathematics problems.

The third highest mean was obtained by difficult problems $($ Mean $=3.64, \mathrm{SD}=0.54)$, which indicated that most of the students have a high tendency to believe in their ability to solve mathematical problem solving questions within the stipulated time. They agreed they could solve mathematics problems that take a long time to be solved if they persistently gave a try and do not simply give up.

Steps had the lowest mean in students' beliefs about mathematical problem solving (Mean $=3.08, \mathrm{SD}=0.58$ ). This showed students believed that there are mathematics problems that cannot be solved by following the procedural method. They agreed that memorizing mathematics steps is ineffective in finding the solutions to solve mathematics problems.

The correlation between students' beliefs on mathematical problem solving and mathematics achievement was tested using the Pearson's correlation analysis to determine whether there is any significant relationship between the variables. The data analysis in Table 2 showed there is a moderate significant positive relationship between the overall beliefs on mathematical problem solving with mathematics achievement $(\mathrm{r}=$ $0.448^{* *}, \mathrm{p}=0.000$ ). It could be concluded that the students with high beliefs on mathematical problem solving tend to obtain high mathematics achievement.
A multiple regression analysis was performed to identify the best predictors that influenced students' achievement in learning mathematics. The assumptions for the sample size, normality, linearity, homoscedasticity and homoscedasticity of residuals had been met. The following model summary table (Table 3) shows the multiple correlation coefficient $(\mathrm{R})$ obtained is 0.497 and the $\mathrm{R}^{2}$ value obtained is 0.247 . The $\mathrm{R}^{2}$ value indicated how much the variance in the dependent variable was explained by the model. The $\mathrm{R}^{2}$ value indicated $24.7 \%$ of the variance in mathematics achievement was explained by the combination of difficult problems, steps and understanding.

Table 3. Model Summary

\begin{tabular}{|c|c|c|c|}
\hline $\mathbf{R}$ & R square & $\begin{array}{c}\text { Adjusted } \mathbf{R} \\
\text { squared }\end{array}$ & $\begin{array}{c}\text { Standard error of the } \\
\text { estimates }\end{array}$ \\
\hline 0.497 & 0.247 & 0.239 & 1.51824 \\
\hline
\end{tabular}

Table 4 shows the results of ANOVA analysis by using the multiple regression model. The statistical test showed it is significant at 0.05 level of significance $[\mathrm{F}(3,308)=$ $33.602, \mathrm{p}=0.000]$ with the $p$-value smaller than 0.05 , indicating the combination of predictors (difficult problems, steps and understanding) significantly predicted mathematics achievement.

Table 4. ANOVA

\begin{tabular}{|c|c|c|c|c|c|}
\hline Model & $\begin{array}{c}\text { Sum of } \\
\text { squares }\end{array}$ & Df & $\begin{array}{c}\text { Mean } \\
\text { square }\end{array}$ & F & Sig. \\
\hline Regression & 232.361 & 3 & 77.454 & 33.602 & 0.000 \\
\hline Residual & 709.959 & 308 & 2.305 & & \\
\hline Total & 942.320 & 311 & & & \\
\hline \multicolumn{6}{|c|}{ Predictors: difficult problem, steps and understanding } \\
Dependent variable: mathematics achievement \\
\hline
\end{tabular}

Table 5 illustrates the results of multiple regression which indicated difficult problems $(t=6.076, p=0.000)$, steps $(t=4.784, p=0.000)$ and understanding $(t=2.030, p$ $=0.043)$ influenced students' mathematics achievement. 
Table 5. Coefficient Multiple Linear Regression for Mathematics Achievement

\begin{tabular}{|c|c|c|c|c|c|}
\hline \multirow[t]{2}{*}{ Model } & \multicolumn{2}{|c|}{ Unstandardized Coefficients } & \multirow{2}{*}{$\frac{\text { Standardized Coefficients }}{\text { Beta }}$} & \multirow{2}{*}{$\mathrm{t}$} & \multirow{2}{*}{ Sig. } \\
\hline & Beta & Standard Error & & & \\
\hline (Constant) & -4.653 & 0.768 & & -5.920 & 0.000 \\
\hline Difficult problems & 1.041 & 0.171 & 0.324 & 6.076 & 0.000 \\
\hline Steps & 0.734 & 0.153 & 0.245 & 4.784 & 0.000 \\
\hline Understanding & 0.328 & 0.162 & 0.106 & 2.030 & 0.043 \\
\hline
\end{tabular}

Generally, the model for predicting students' beliefs on mathematical problem solving is as follows:

$$
\hat{Y}=-4.653+1.041 x_{1}+0.734 x_{2}+0.328 x_{3}+\varepsilon
$$

where:

$$
\begin{array}{ccc}
\hat{Y} & = & \text { Mathematics achievement } \\
X_{1} & = & \text { Difficult problems } \\
X_{2} & = & \text { Steps } \\
X_{3} & = & \text { Understanding } \\
\varepsilon & = & \text { Error }
\end{array}
$$

Further analysis indicated that only the constructs, difficult problems, steps and understanding were factors that influenced students' mathematics achievement. The strongest predictors were the students' beliefs on difficult problems or time-consuming problems. A possible interpretation for this might be that students were convinced they could solve mathematics problems that take a long time to be solved if they persistently gave a try and do not simply give up. Furthermore, in their study, Stylianides and Stylianides [3] found difficult problems that students viewed as impossible to be solved could be solved within their abilities. Therefore, putting more positive beliefs on efforts can improve mathematics ability, whereby Malaysian matriculation students can increase their achievement in solving mathematics problems.

\section{Conclusions}

The overall mean mathematics beliefs obtained showed that respondents had high level of mathematics beliefs in problem solving, and thus suggesting that they held positive beliefs about mathematical problem solving. The high level of mathematics beliefs is also supported by Abedalaziz and Akmar [1]. High mathematics beliefs were identified in this study because respondents perceived their effort in mathematics learning will result in their increased mathematics ability. Besides, they also believed that they can solve mathematics problems and improve mathematics ability by studying harder. Therefore, they would persistently give a try and they would not simply give up when solving difficult mathematics problems.

A significant relationship was found between beliefs on mathematical problem solving and mathematics achievement in this study; and this is not surprising because students' problem solving beliefs is important to increase their ability to solve mathematics problems correctly. Therefore, it is important to increase students' positive beliefs about mathematical problem solving and hence further improve the strategy they take in solving mathematics problems. Therefore, this study suggests that matriculation educators could help students to gradually change naive representations about how they view mathematics and the implications of beliefs in learning mathematical problem solving. If students have positive beliefs in mathematical problem solving, there are expected to get high mathematics achievement.

The findings of this study on matriculation students have come up with an important information on factors that influence the mathematics achievement on mathematical problem solving. From the five factors examined on the students' beliefs, three factors, i.e. difficult problems, steps and understanding influence students' mathematics achievement. Students with high positive beliefs in these three beliefs factors were able to increase their ability and mathematics achievement. Thus, mathematics educators should carry out more learning activities to increase students' perception of the usefulness and the importance of mathematical problem solving before they enrol into tertiary education. Besides that, they should continuously implement problem solving skills in teaching and learning activities in the classroom to improve the skills that they had learned in secondary school.

\section{REFERENCES}

[1] Abedalaziz, N., \& Akmar, S. N. Epistemology beliefs about mathematical problem solving among Malaysian students, OIDA International Journal of Sustainable Development, 5(1), 59-74, 2012.

[2] Suthar, V., Tarmizi, R. A., Midi, H., \& Adam, M. B. (2010). Students' beliefs on mathematics and achievement of university students: Logistics regression analysis, Procedia - Social and Behavioral Sciences, 8(5), 525-531, 2010.

[3] Stylianides, A. J., \& Stylianides, G. J. Impacting positively on students' mathematical problem solving beliefs: An instructional intervention of short duration, Journal of Mathematical Behavior, 33(1), 8-29, 2014. 
[4] McNeill, N. J., Douglas, E. P., Koro-Ljungberg, M., Therriault, D. J., \& Krause, I. Undergraduate students' beliefs about engineering problem solving, Journal of Engineering Education, 105(4), 560-584, 2016.

[5] Ozturk, T., \& Guven, B. Evaluating students' beliefs in problem solving process: A case study. Eurasia Journal of Mathematics, Science \& Technology Education, 12(2), 411-429, 2016.

[6] Kloosterman, P., Beliefs about mathematics and mathematics learning in the secondary school: Measurement and implications for motivation. In G. C. Leder, E. Pehkonen, \& G. Törner (Eds.). In Beliefs: A Hidden Variable in Mathematics Education, Kluwer Academic Publishers, Dordrecht, 2002.

[7] Mason, L., \& Scrivani, L. Enhancing students' mathematical beliefs: An intervention study, Learning and Instruction, 14, 153-176, 2004.

[8] Lerch, C. M. Control decisions and personal beliefs: Their effect on solving mathematical problems, Journal of Mathematical Behavior, 23, 21-36, 2004.

[9] Garcia, G. C. Students' beliefs toward mathematics as related to their performance in college algebra, JPAIR Multidisciplinary Research, 9, 93-105, 2012.

[10] Abdul Kadir, M. H., Ahmad Tarmizi, R., \& Syed Hussain, S. K. Impak tingkah laku dan kepercayaan semasa penyelesaian masalah matematik terhadap pencapaian masalah matematik, Jurnal Pendidikan Sains \& Matematik Malaysia, 5(2), 41-50, 2015.

[11] Radzali, R., Meerah, T. S. M., \& Zakaria, E. Hubungan kepercayaan matematik, metakognisi dan perwakilan masalah dengan kejayaan penyelesaian masalah matematik, Jurnal Pendidikan Malaysia, 35(2), 1-7, 2010.

[12] Guven, B., \& Cabakcor, B. O. Factors influencing mathematical problem-solving achievement of seventh grade Turkish students, Learning and Individual Differences, 23(1), 131-137, 2013.

[13] Kamalimoghaddam, H., Ahmad Tarmizi, R., Mohd Ayub, A. F., \& Wan Jaafar, W. M. The influences of mathematics beliefs on mathematics achievement through mathematics self-efficacy: A structural equation model, Communication in Mathematical Modeling and Applications, 51(1), 44-51, 2016.

[14] Burrus, J., \& Moore, R. The incremental validity of beliefs and attitudes for predicting mathematics achievement, Learning and Individual Differences, 50, 246-251, 2016.

[15] Schoenfeld, A. H. Beyond the purely cognitive: Belief systems, social cognitions, and metacognitions as driving forces in intellectual performance, Cognitive Science, 7(4), 329-363, 1983.

[16] Schoenfeld, A. H. Mathematical Problem Solving, Academic Press. Inc, Orlando, Florida, 1985.

[17] Mason, L. High school students' beliefs about maths, mathematical problem solving, and their achievement in maths: A cross-sectional study, Educational Psychology: An International Journal of Experimental Educational Psychology, 23(1), 73-85, 2003.

[18] Kloosterman, P., \& Stage, F. K. Measuring Beliefs about
Mathematical Problem Solving. School Science and Mathematics, 92(March), 109-115, 1992.

[19] Hair, J. F., Black, W. C., Babin, B. J., \& Anderson, R. E. Multivariate Data Analysis (7th ed.), Pearson Prentice Hall, New Jersey, 2010. 